Vol 5 No 1 Maret 2018

\title{
Tanggung Jawab Para Pihak Dalam Pembuatan Akta Jaminan Fidusia Pada Notaris Di Busan Auto Finance Rembang
}

\author{
Magmun Migfar*, Amin Purnawan ${ }^{* *}$ \\ * Mahasiswa Program Magister (S2) Kenotariatan Fakultas Hukum UNISSULA, Semarang email : e-mail \\ magmunmigfar.mkn03@gmail.com \\ ** Dosen Fakultas Hukum UNISSULA
}

\begin{abstract}
ABSTRAK
Dalam memberikan kredit, Perusahaan Pembiayaan wajib mempunyai keyakinan didasarkan pada unsur perinsip kehati-hatian biasa di kenal dengan 5C, yaitu terdiri dari character (watak), capacity (kemampuan), capital (modal), collateral (jaminan), dan condition of economic (kondisi ekonomi).Di dalam penelitian penulis membuat rumusan masalahanuntuk mengetahui tanggung jawab para pihak dalam pembutan akta jaminan fidusia pada Notaris dan penyelesaian sengketanya apabila debitur mengalihkan objek jaminan fidusia tanpa persetujuan tertulis oleh pihak PT. Bussan auto Finance (BAF) Rembang.Penelitian ini merupakan penelitian yang bersifat diskriptif dan apabila dilihat dari tujuannya teremasuk penelitian hukum empiris. Lokasi penelitian di PT. BAF Rembang. Jenis data yang digunakan meliputi data primer dan data sekunder. Teknik pengumpulan data yang dipergunakan yaitu melalui penelitian kepustakaan dan wawancara. Analisis data menggunakan kualitatif analitis. Berdasarkan hasil penelitian dapat diketahui dalam perjanjian pembiayaan antara kreditur dan debitur saling mengikatkan diri, debitur harus membaca dan memahami surat perjanjian pembiayaan, sebelum melakukan kesepakatan sengan Leasing, setelah menandatangi perjanjian pembiayaan, debitur harus memenuhi kewajiban membayar angsuran secara tepat waktu sesuai dengan besaran dan tanggal yang telah disepakati, kemudian timbulah hak dan kewajiban supaya jangan sampai ada konflik atau kesalah pahaman yang bias merugikan debitur dikemudian hari.Dalam hal benda jaminan yang menjadi objek jaminan fidusia dialihkan kepada pihak ketiga berlaku asas drot de suite, kreditur tetap dapat mengeksekusi benda jaminan tersebut di tangan siapaun benda tersebut berada. Pengalihan benda yang menjadi objek jaminan fidusia pada pihak ketiga dan seterusnya tidak menghalangi hak kreditur untuk tetap mengeksekusi benda jaminan fidusia tersebut. Memang dalam peneyelesain sengketa benda jamian fidusia di PT BAF Rembang masih mengedepankan cara musyawarah dahulu akan tetapi jika PT BAF Rembang berpedoman pada POJK No.29/POJK.05/2014 Tentang Penyelenggaraan Usaha Perusahaan Pembiayaan dan perlu adanya pendampingan dai pihak kepolisian maka akan sangat mudah dan mungkin untuk mengatasi debitur yang nakal.
\end{abstract}

Kata kunci : Debitur, Kreditur, Eksekusi Benda Jaminan Fidusia.

\section{ABSTRACT}

In granting credit, a Financing Company must have confidence based on the usual principle of prudence known as 5C, which consists of character, capability, capital, collateral and condition of economic ( economic conditions). In the study the authors make the formulation of the problem to know the responsibility of the parties in the fiduciary guarantee certificate pembutan notary and settlement of disputes if the debtor divert the fiduciary guarantee object without written approval by the PT. Bussan auto Finance (BAF) Rembang.Penelitian is a descriptive study and when viewed from its purpose including research empirical law. Research location at PT. BAF Rembang. Types of data used include primary data and secondary data. Data collection techniques used are through literature research and interviews. Analytical data use qualitative analytical.

Based on the results of the research can be known in the financing agreement between the creditor and the debtor bind each other, the debtor must read and understand the letter of financing agreement, before making leasing agreement, after signing the financing agreement, the debtor must meet the obligation to pay installments in a timely manner in accordance with the amount and date which has been agreed, then arise rights and obligations so that there will be no conflicts or misunderstandings that bias detrimental to the debtor in the future. In the event that the collateral object becomes the object of fiduciary guarantee transferred to a third party applies the principle of drot de suite, the lender can still execute the guarantee object in the hands of whoever the object is located. The transfer of objects which become the object of fiduciary collateral to a third party and so on shall not preclude the right of the creditor to keep executing the fiduciary assurance object. 
Indeed, in peneyelesain dispute fiduciary jamian objects in PT BAF Rembang still put forward the first musyawarah way but if PT BAF Rembang based on POJK No.29 / POJK.05 / 2014 About the Implementation of Financing Company Business and the need for assistance from the police then it will be very easy and possibly to deal with naughty debtors.

Keywords: Debtor, Creditors, Execution of Fiduciary Guarantee Items.

\section{PENDAHULUAN}

Begitu banyak keluhan terhadap membanjirnya sepeda motor.Tapi saya mencatatnya sebagai dewa penolong. Motor, bagi saya, adalah sarana transportasi yang memberikan kesempatan bagi rakyat kecil untuk mengejer ketertinggalannya. Sepeda motor adalah alat yang paling tepat untuk membawa golongan bawah memiliki kesempatan masuk menjadi golongan menengah. Demikian juga dengan sepeda motor.Produktifitas golongan bawah langsung bisa mengalami kenaikan yang drastis. Ini karena golongan pemilik sepeda motor bisa memiliki mobilitas yang sama tingginya dengan golongan tas. Biaya untuk angkutan umum itu bisa mencapai $80 \%$ dari gaji mereka. Untuk apa bekerja kalau $80 \%$ gaji habis untuk kendaraan? Pilihan bagi mereka tidak sebanyak itu. Tidak bekerja berarti tidak punya penghasilan sama sekali. Dengan tetap bekerja, setidaknya eksistensi dan kehormatan sebagai manusia tetap terjaga.Kini, dengan kemudahan system keuangan, prosentase biaya transportasi itu bisa membaik. Dengan system kredit sepeda motor yang kian ringan tidak perlu lagi ada uang di depan yang terlalu besar. Memang semasa cicilan belum lunas prosentase pengeluarannya tetap tinggi, tapi turun drastis setelah masa cicilan sepeda motornya selesai. ${ }^{1}$

Dalam memberikan kredit, kreditur wajib mempunyai keyakinan seperti tersebut diatas didasarkan pada unsur prinsip kehati-hatianng dikenal dengan 5C's analyses, yaitu terdiri dari character (watak), capacity (kemampuan), capital (modal), collateral (jaminan), dan condition of economic (kondisi ekonomi). ${ }^{2}$

Bussan Auto Finance (BAF) merupakan merupakan perusahaan di bidang pembiayaan dengan berkonsentrasi kepada pembiayaan sepeda

\footnotetext{
${ }^{1}$ https://dahlaniskan.wodpress.com diunduh tanggal 01 Juli 2017

2 Djuhaendah Hasan, 1996, Lembaga Jaminan Kebendaan Bagi Tanah dan Benda Lain yang

Melekat Pada Tanah Dalam Konsepsi Penetapan Asas Pemisahan Horizontal, PT. Citra Aditya Bakti, Bandung, h. 12
}

motor Yamaha. Dengan seiring pertumbuhan dan perkembangan kebutuhan masyarakat kami turut berinovasi untuk menjadi solusi pembiayaan bagi kebutuhan masyarakat dengan membuka berbagai jenis pembiayaan lainnya seperti pembiayaan multiproduk, mesin pertainan, mobil juga pembiayaan kembali. Bussan Auto Finance (BAF) telah terdaftar dalam Asosiasi Perusahaan Pembiayaan Indonesia (APPI) dan juga Biro Kredit. Dalam melaksanakan bisnisnya Bussan Auto Finance (BAF) terdaftar dan di awasi oleh Otoritas Jasa keuangan (OJK).Adapun misi Bussan Auto Finance (BAF) menjadi perusahaan pembiayaan terkemuka dan terpercaya bagi pelanggan, mitra usaha dan masyarakat, dan misinya adalah member pelayanan solusi keuangan terbaik untukmeningkatkan kesejahtraan hidup masyarakat.

PT Bussan Auto Finance (BAF) didirikan pada tahun 1997 dan merupakan perusahaan pembiayaan yang saat ini berkonsentrasi pada pembiayaan motor Yamaha. Saat ini BAF memiliki 173 kantor cabang di seluruh pelosok Nusantara, dengan jumlah karyawan lebih dari 10,000 orang. Total jumlah konsumen yang pernah dan sedang dibiayai oleh BAF telah mencapai lebih dari 4 juta orang. Selama tahun 2009, BAF membiayai lebih dari 714 ribu unit kendaraan bermotor baru dengan total asset lebih dari 10 triliun rupiah. $^{3}$

Lembaga jaminan mempunyai arti yang sangat penting dalam menunjang pembangunan ekonomi, yang secara langsung maupun tidak langsung memberikan manfaat bagi kreditur dan debitur; adapun manfaatnya bagi kreditur yaitu: 1) Terwujudnya keamanan dalam transaksi antara kreditur dan debitur. Maksudnya kredit atau modal yang diserahkan oleh kreditur kepada debitur, kreditur tidak merasa takut dan khawatir jika modal yang diserahkan kepada debitur tidak akan dikembalikan; 2) Memberikan kepastian hukum, maksudnya kepastian bagi kreditur untuk menerima pengembalian pokok kredit dan bunga, kreditur atau pemilik modal dapat melakukan eksekusi terhadap

\footnotetext{
${ }^{3}$ https://www.cermati.com diunduh tanggal 10 Agustus 2017
} 
benda jaminan fidusia (pengembalian secara paksa).

Manfaat bagi debitur yaitu: 1) Memperoleh fasilitas kredit untuk pembiayaan; 2) Tidak ada kekhawatiran dalam pengembangan usahanya karena adanya kepastian dalam berusaha, dengan modal yang dimiliki dapat mengembangkan bisnis lebih lanjut. ${ }^{4}$

Menurut Pasal 1 angka 7 Peraturan Presiden Republik Indonesia No. 9 Tahun 2009 tentang Lembaga Pembiayaan, pembiayaan konsumen (consumer finance) adalah kegiatan pembiayaan untuk pengadaan barang berdasarkan kebutuhan konsumen dengan pembayaran secara angsuran. Sedangkan sewa guna usaha (leasing) adalah kegiatan pembiayaan dalam bentuk penyediaan barang modal baik secara sewa guna usaha dengan hak opsi (finance lease) maupun sewa guna usaha tanpa hak opsi (operating lease) untuk digunakan oleh penyewa guna usaha (lease) selam jangka waktu tertentu berdasarkan pembayaran secara angsuran.

Sebagaimana dikutip dari artikel artikel yang berjudul Kesimpulan perkara Gugatan Perdata Terkait Sita Mobil Kredit oleh Perusahaan Pembiayaan Konsumen menurut Budi Rachmad dalam bukunya yang berjudul Multi Finance Sewa Guna Usaha Anjak Piutang Pembiayaan Konsumen (hal 137) perbedaan pembiayaan konsumen dengan sewa guna usaha khususnya dengan hak opsi (finance lease) adalah sebagai berikut:

1. Pada pembiayaan konsumen pemilikian barang objek jaminan berada pada konsumen. Adapun pada sewa guna usaha pemilikan barang objek pembiayaan berada pada lessor.

2. Pada pembiayaan konsumen tidak ada batasan waktu pembiayaan dalam arti disesuaikan dengan unsure ekonomis barang objek pembiayaan. Adapun pada sewa guna usaha jangka waktu diatur sesuai dengan umur ekonomis objek barang modal yang dibiayai oleh lessor.

3. Pada pembiayaan konsumen tidak membatasi pembiayaan kepada calon konsumen yang telah mempunyai Nomor Wajib Pajak (NPWP) mempunyai kegiatan usaha dan atau pekerjaan bebas. Adapun pada sewa guna usaha calon lessee diharuskan ada atau memiliki syarat-syarat diatas. $^{5}$

\footnotetext{
${ }^{4}$ M. Ali Mansyur, 2011, Hukum Perdata Jaminan, Bagian Hukum Perdata F.H. UNISSULA, Semarang, h. 1

${ }^{5}$ http:/www.hukumomline.com diunduh tanggal 1 Juli 2017
}

Salah satu wujud dari pemberian kepastian hukum hak-hak kreditur adalah dengan mengadakan lembaga pendaftaran jaminan fidusia dan tujuan pendaftaran itu tidak lain adalah menjamin kepentingan dari pihak yang menerima fidusia. ${ }^{6}$ Adapun bentuk perlindungan yang dimliki oleh seorang kreditur terhadap barang jaminan yang sudah didaftarkan yaitu; hak privelege (Pasal 1139 ayat (3) jo, Pasal 1144 KUHPerdata), hak reklame (Pasal 1145 KUHPerdata jo, Pasal 230 KUHDagang), syarat batal (Pasal 1266 KUHPerdata) dan beding dengan syarat menangguhkan peralihan hak miliknya. ${ }^{7}$ Tidak hal perlindungan hukum yang didapat kreditur melalui UUJF, akan tetapi di dalam Peraturan Menteri Keuangan Nomor 130/PMK.010/ 2012 dan itu terasa ada nuansa perlindungan konsumen, yaitu:

1) Perusahaan pembiayaan yang melakukan pembiayaan konsumen untuk kendaraan bermotor dengan pembebanan jaminan fidusia wajib mendaftarkan jaminan fidusia dimaksud pada kantor pendaftaran fidusia.

2) Kewajiban pendaftaran jaminan fidusia tersebut berlaku pula bagi perusahaan pembiayaan yang melakukan pembiayaan konsumen kendaraan bermotor berdasar prinsip syariah dan/atau pembiayaan konsumen kendaraan bermotor yang pembiayaannya berasal dari pembiayaan penerusan (channeling) atau pembiayaan bersama (joint financing).

3) Perusahaan pembiayaan wajib mendaftarkan jaminan fidusia pada kantor pendaftaran fidusia paling lama 30 hari kalender terhitung sejak tanggal perjanjian pembiayaan konsumen.

4) Perusahaan pembiayaan dilarang melakukan penarikan benda jaminan fidusia berupa kendaraan bermotor jika kantor pendaftaran fidusia belum menerbitkan sertifikat jaminan fidusia dan menyerahkannya kepada perusahaan pembiayaan.

5) Penarikan benda jaminan fidusia berupa kendaraan bermotor oleh perusahaan pembiayaan wajib memenuhi ketentuan dan persyaratan sebagaimana diatur di dalam UU JF dan telah disepakati oleh para pihak dalam

\footnotetext{
6 J. Satrio, 2002, Hukum Jaminan Hak Jaminan Kebendaan Fidusia, PT, Citra Aditya Bakti, Bandung, h. 143

7 Herlien Boediono, 2012, Kumpulan Tulisan HUKUM PERDATA dibidang KENOTARIATAN, Citra Aditya Bakti, $\mathrm{h}$. 106
} 
perjanjian pembiayaan konsumen kendaraan bermotor. $^{8}$

6) Bagi setiap perusahaan pembiayaan yang melanggar setiap ketentuan tersebut maka akan dikenakan sanksi administratif yang berupa peringatan, pembekuan kegiatan usaha, atau pencabutan izin usaha. Sementara jaminan fidusia dapat menjamin utang seperti: utang yang telah ada, utang yang akan timbul di kemudian hari dan telah dijanjikan dalam jumlah tertentu, serta utang pada saat eksekusi yang dapat ditentukan jumlahnya berdasarkan perjanjian pokok dan menimbulkan kewajiban pemenuhan prestasi. ${ }^{9}$

Hak dan kewajiban debitur adalah bertimbal balik dengan hak dan kewajiban kreditur. Selama proses ini tidak menghadapi masalah dalam arti kedua belah pihak melaksanakan hak dan kwajibannya sesuai dengan apa yang diperjanjikan, maka persoalan tidak akan muncul. Biasanya persoalan baru muncul jika debitur lalai mengembalikan uang pinjaman pada saat yang telah diperjanjikan. ${ }^{10}$

Kontruksi fidusia adalah penyerahan hak milik atas barang kepunyaan debitur kepada kreditur sedang penguasaan fisik atas barang-barang itu tetap pada debitur (Constitutum Possesorium) dengan syarat bahwa bilamana debitur melunasi hutangnya, maka kreditur harus mengembalikan hak milik atas barang-barang itu kepada debitur. ${ }^{11}$ Berdasarkan Pasal 4 Undang-Undang NNo. 42 Tahun 1999 tentang Jaminan Fidusia, bahwa jaminan fidusia adalah perjanjian accessoir berarti bahwa lahir dan hapusnya perjanjian jaminan fidusia bergantung pada perjanjian pokoknya (perjanjian utang-piutang atau perjanjian pembiayaan)

Suatu prinsip yang berlaku pada hukum jaminan adalah kreditur tidak dapat meminta suatu janji agar memiliki benda yang dijaminkan bagi pelunasan hutang debitur kepada kreditur. Ratio dari ketentuanini adalah untuk mencegah terjadinya ketidak adilan yang akan terjadi jika kreditur memilik benda jaminan yang nilainya lebih besar dari jumlah hutang debitur kepada kreditur. Karena itu, benda jaminan tersebut harus dijual dan kreditur berhak

\footnotetext{
${ }^{8}$ http://mdn.biz.id/n/154879/ diunduhtanggal 1 Juli 2017

${ }^{9}$ http://Gatranews.com diunduh tanggal 1 Juli 2017

10 Gunawan Widjaya dan Ahmad Yani, 2001, Jaminan Fidusia, Raja Grafindo Persada, Jakarta, h. 3

${ }^{11}$ Munir Fuady, 2003, Jaminan Fidusia Revisi Kedua, Citra Aditya Bakti, Jakarta, h. 10
}

mengambil uang hasil penjualan tersebut sebagai pelunasan piutangnya.Apabila masih ada kelebihan maka sisa hasil penjualan harus dikembalikan kepada kreditur. ${ }^{12}$

Pembebanan Fidusia dilakukan dengan menggunakan instrument yang disebut dengan AKTA JAMINAN FIDUSIA, yang harus memenuhi syaratsyarat yaitu berupa Akta Notaris dan didaftarkan pada Pejabat yang berwenang. Dengan pendaftaran ini, diharapkan agar pihak debitur, terutama yang nakal, tidak dapat lagi mengibuli kreditur atau calon kreditur dengan memfidusiakan sekali lagi atau bahkan menjual barang Obyek Jaminan Fidusia tanpa sepengetahuan kreditur asal di Kantor Pendaftaran Fidusia yang berada dibawah naungan Departemen Hukum dan HAM R.I.. Sertipikat Jaminan Fidusia sebagai bukti bahwa penerima Fidusia memiliki hak Fidusia tersebut. ${ }^{13}$

Jika perusahaan pembiayaan tersebut tidak mendaftarkan perjanjian jaminan fidusia, maka perusahaan pembiayaan tersebut tidak dilindungi hak-haknya oleh UU JF.Ini berarti perusahaan pembiayaan tersebut tidak memiliki hak untuk didahulukan daripada kreditur-kreditur lain untuk mendapatkan pelunasan utang debitur dari benda yang dijadikan jaminan fidusia tersebut (pasal $27 \mathrm{UU}$ JF).Karena itu, perusahaan pembiayaan alias leasing wajib mendaftarkan jaminan fidusia atau benda jaminan. Tanpa fidusia, pihak kepolisian tidak berkewajiban memproses pengaduan pihak leasing. Ketentuan ini diatur di dalam UU No. 42 Tahun 1999 tentang Jaminan Fidusia.Jaminan fidusia memberikan kedudukan yang diutamakan privilege kepada penerima fidusia terhadap kreditor lainnya.

Bila ada perusahaan leasing yang tidak mendaftarkan jaminan fidusia kepada Kantor Pendaftaran Fidusia.Konsumen malah dirugikan sebab perjanjian fidusia itu tidak berlaku.Peristiwa seperti ini masih menjamur padahal konsumen sudah menandatangani perjanjian bahwa mereka setuju untuk memberikan hak kepemilikan kepada multifinance sampai kendaraan lunas.Oleh karena itu sering terjadi perjanjian fidusia "bawah tangan". ${ }^{14}$

Pasal 2 Peraturan Menteri Keuangan No. 130/PMK.010/2012 menyebutkan, perusahaan pembiayaan wajib mendaftarkan jaminan fidusia

\footnotetext{
12 Suharnoko, 2004, Hukum Perjanjian Teori dan Analisis Kasus, Prenada Media, Jakarta, h. 22

13 Agus Pramudijono, Sekretaris Cabang Asosiasi Advokat Indonesia (AAI) Surabaya, Dosen dan Praktisi Hukum.

${ }^{14}$ http://Gatranews.com Op.cit diundu tanggal 1 Juli 2017
} 
pada kantor pendaftaran fidusia paling lama 30 hari kalender terhitung sejak tanggal perjanjian pembiayaan konsumen. Dalam sertifikat jaminan fidusia dicantumkan kata-kata "Demi Keadilan Berdasarkan Ketuhanan Yang Maha Esa".Sertifikat tersebut mempunyai eksekutorial dipersamakan dengan putusan pengadilan yang memperoleh kekuatan hukum tetap. Artinya, sertifikat jaminan fidusia bisa langsung dieksekusi tanpa proses persidangan dan pemeriksaan melalui pengadilan, bersifat final serta mengikat para pihak untuk melaksanakan putusan tersebut.

Peraturan ini bukan berarti bisa menjadi alasan bagi nasabah untuk dengan sengaja tidak membayar cicilan atau menunggak pembayaran kredit kendaraannya.Pihak leasing masih berhak menarik benda jaminan berupa kendaraan bermotor asal memenuhi ketentuan dan persyaratan yang telah diatur di dalam undang-undang mengenai jaminan fidusia dan telah disepakati para pihak dalam perjanjian konsumen kendaraan bermotor.

\section{Metode Penelitian}

Metode Pendekatan dalam penulisan ini menggunakan metode pendekatan Yuridis Empiris, merupakan pendakatan terhadap hukum positif atau peraturan perundang-undangan, maksudnya adalah merupakan pendekatan dengan memaparkan, menganalisis dan mengevaluasi peraturan perundang-undangan yang berkaitan dengan akta jaminan fidusia yang di buat oleh Notaris dan pelaksanaan perjanjian jaminan fidusia di Bussan Auto Finance (BAF) Rembang. Spesifikasi dalam penulisan penelitian ini berupa penelitian diskriptif analitis.Diskriptif dalam arti bahwa dalam penelitian ini penulis bermaksud untuk menggambarkan dan melaporkan secara rinci, sistematis, dan menyeluruh mengenai segala sesuatu yang berkaitan akta jaminan fidusia yang dibuat oleh Noatris dan perjanjian jaminan fidusia antara kreditur dan debitur.

Sebelum sampai pada penentuan responden terlebih dahulu ditentukan populasinya sebagai sumber informasi, karena populasi adalah keseluruhan atau himpunan obyek dengan ciri-ciri yang sama. ${ }^{15}$ Sedangkan menurut Soerjono Soekanto, populasi adalah sejumlah manusia atau unit yang mempunyai ciri-ciri atau karakteristi yang

\footnotetext{
15 Bambang Sunggono, 1998, Metode Penelitian Hukum, Raja Grafindo Persada, Jakarta, h. 121
}

sama. ${ }^{16}$ Dalam penelitian ini, populasi yang diteliti adalah pihak-pihak yang ada kaitannya dengan perlindungan hukum bagi kreditur jaminan fidusia jika terjadi wanprestasi.

Dalam penelitian ini, pengambilan sempel menggunakan teknik random sampling, karena jenis yang digunakan adalah metode purposive sampling, yaitu penarikan sampel dilakukan dengan caramengambil subjek berdasarkan pada tujuan tertentu. Teknik non random sampling dipilih karena alas an keterbatasan waktu, tenaga, dan biaya berdasarkan tujuan tertentu yang memenuhi persyaratan sebagai berikut: ${ }^{17}$ Harus didasarkan pada ciri-ciri, sifat-sifat, atau karakteristik tertentu yang merupakan cirri utama populasi; Subjek yang diambil sebagai sempel harus benar-benar merupakan subjek yang paling mengandung ciri-ciri yang terdapat pada populasi; Penentuan karakteristik populasi dilakukan dengan teliti dalam studi pendahuluan.

Responden dalam penelitian ini adalah pihakpihak yang berhubungan dengan subjek penelitian, yakni konsumen / debitur, PT. Bussan Auto Finance (BAF) Rembang, Dealer atau Showroom dan notaris

Pengumpulan data merupakan hal yang sangat erat hubungannya dengan sumber data, karena melalui pengumpulan data ini akan diperoleh data yang diperlukan untuk selanjutnya dianalisa sesuai yang diharapkan berkaitan dengan hal tersebut, maka dalam penelitian ini penulis menggunakan pengumpulan data sebagai berikut: Data Primer dan Data Sekunder.

Data primer yaitu data yang diperoleh secara langsung dari Respoden dan data primer diperoleh dengan: Wawancara, yaitu cara memperoleh informasi dengan bertanya secara langsung kepada respoden dalam hal ini PT. Bussan Auto Finance (BAF) Rembang, Dealer atau Showroom , Debitur dan Notaris guna mengetahui dan terkait dengan akta jaminan fidusia yang dibuatnya dan perjanjian jaminan fidusia antara kreditur dan debitur.

Sistem wawancara yang dipergunakan dalam penulisan ini dalah wawancara bebas terpimpin, artinya terlebih dahulu dipesiapkan daftar pertanyaan sebagai pedoman tetapi masih dimungkinkan adanya variasi pertanyaan yang disesuaikan dengan situasi

\footnotetext{
16 Soerjono Soekanto, 1986, Pengantar Penelitian Hukum, Universitas Indonesia Pers, Jakarta, h. 172

17 Rony Hanitijo Soemitro, 1988, Metode Penelitian Hukum dan Jurimetri, Ghalia Indonesia, Jakarta, h. 15
} 
pada saat wawancara dilakukan. Daftar pertanyaan, yaitu daftar pertanyaan yang diajukan kepada pihak responden yang terkait akta jaminan fidusia dan perjanjian jaminan fidusia untuk memperoleh jawaban secara tertulis. Dalam hal ini, daftar pertanyaa diberikan kepada responden.

Data Sekunder, Data sekunder yaitu data yang mendukung keterangan atau menunjang kelengkapan data primer. Data sekunder terdiri dari: Bahan-bahan hukum primer, sekunder dan tersier.

Bahan-bahan hukum primer, meliputi: Kitab Undang-Undang Hukum Perdata, Undang-Undang Nomor 10 Tahun 1998 tentang Perbankan, UndangUndang Nomor 8 Tahun 1999 tentang Perlindungan Konsumen, Undang-Undang Nomor 42 Tahun 1999 tentang Jaminan Fidusia, Undang-Undang Nomor 2 Tahun 2014 tentang Jabatan Notaris, Peraturan Pemerintah Nomor 21 Tahun 2015 tentang Tata Cara Pendaftaran Jaminan Fidusia dan Biaya Pembuatan Akta Jaminan Fidusia, Peraturan Menteri Keuangan RI Nomor 130 /PMK.010/Tahun 2012 tentang Pendaftaran Jaminan Fidusia bagi Perusahaan Pembiayaan yang Melakukan pembiayaan Konsumen Untuk Kendaraan Bermotor dengan Pembebanan Jaminan Fidusia, Surat Keputusan Direksi Bank Indonesia No. 23/88/KEP/DIR Tahun 1991 tentang Jaminan Pemberian Kredit.

Bahan-bahan hukum sekunder, yaitu bahanbahan yang erat hubungannya dengan bahan hukum primer dan dapat membantu menganalisa dan memahami bahan hukum primer, meliputi: Bukubuku yang membahas tentang Penyelesaian Perjanjian Kredit, Buku-buku yang membahas tentang Notaris, Makalah-makalah seminar yang berkaitan dengan Jamiana Fidusia, Hasil penelitian tentang Penyelesaian Jaminan Fidusia.

Bahan hukum tersier, yang dapat memberikan petunjuk maupun penjelasan terhadap hukum primer dan bahan hukum sekunder yaitu: Kamus, Ensiklopedia, Internet, dan Indeks komulatif yang ada hubungannya dengan penelitian.

Metode Analisa Data, yang digunakan untuk menganalisa data adalah kualitatif analitis, yaitu dari bahan hukum yang telah dikumpulkan sesuai dengan permasalahan yang diteliti kemudian dianalisis secara kualitatif sehingga dapat menghasilkan suatu kesimpulan yang digunakan untuk menjawab masalah yang dibahas.

\section{HASIL PENELITIAN DAN PEMBAHASAN}

Sebelum penulis memaparkan hasil penelitian dan pembahasan, terlebih dahulu penulis akan memberi gambaran profil singkat dari PT. Bussan Auto Finance (BAF).

Bussan Auto Finance (BAF) merupakan merupakan perusahaan di bidang pembiayaan dengan berkonsentrasi kepada pembiayaan sepeda motor Yamaha. Dengan seiring pertumbuhan dan perkembangan kebutuhan masyarakat kami turut berinovasi untuk menjadi solusi pembiayaan bagi kebutuhan masyarakat dengan membuka berbagai jenis pembiayaan lainnya seperti pembiayaan multiproduk, mesin pertainan, mobil juga pembiayaan kembali. Bussan Auto Finance (BAF) telah terdaftar dalam Asosiasi Perusahaan Pembiayaan Indonesia (APPI) dan juga Biro Kredit. Dalam melaksa- nakan bisnisnya Bussan Auto Finance (BAF) terdaftar dan di awasi oleh Otoritas Jasa keuangan (OJK). Adapun misi Bussan Auto Finance (BAF) menjadi perusahaan pembiayaan terkemuka dan terpercaya bagi pelanggan, mitra usaha dan masyarakat, dan misinya adalah member pelayanan solusi keuangan terbaik untukmeningkatkan kesejahtraan hidup masyarakat.

Adapun jenis-jenis pembiayaan di Bussan Auto Finance (BAF) terdiri:

\section{Pembiayaan Roda Dua}

Bussan Auto Finance hadir sebagai perusahaan pembiayaan untuk memenuhi kebutuhan masyakarat untuk memiliki sepeda motor. BAF terus berupaya untuk senantiasa menjaga hubungan antara BAF, Yamaha dan Pelanggan dengan memberikan pelayanan Cepat, Ringan dan Aman (CeRiA).

a. BAF CeRiA memberikan keuntungan dan dapat dinikmati setiap kalangan masyarakat yang ingin mengajukan pembiayaan kendaraan bermotor roda dua merek Yamaha di BAF. BAF CeRiA dapat dinikmati di seluruh cabang yang tersebar di pelosok nusantara.

b. Pelayanan Cepat merupakan pelayanan yang diberikan BAF kepada pelanggan dan dealer Yamaha ketika terdapat pengajuan kredit, ketika pelanggan melakukan pembayaran angsuran, maupun saat pengurusan terkait surat kendaraan bermotor dan hal lainnya.

c. Pelayanan Ringan adalah suatu bentuk pelayanan yang memberikan suku bunga kompetitif dan jumlah angsuran yang ringan serta pembayaran angsuran yang memberikan kemudahan yaitu dengan telah terjalinnya kerjasama yang dibina antara BAF dengan beberapa Bank dan perusahaan perusahaan diantaranya BRI, BCA, 
Vol 5 No 1 Maret 2018

BUKOPIN, BNP, SWAMITRA, ALFAMART, INDOMARET, KANTOR POS, TEKTAYA dan beberapa perusahaan lain dimana konsumen bisa membayar angsuran lewat ATM dan Kasir bank tersebut.

d. Pelayanan Aman merupakan suatu pelayanan yang diberikan oleh BAF terhadap segala proses penyimpanan dokumen dan data pelanggan ke dalam suatu system yang terpercaya.

2. Pembiayaan Mesin Pertanian atau Agriculture Financing (Pembiayaan Mesin Pertanian)

Bussan Auto Finance menyediakan fasilitas pembiayaan mesin-mesin pertanian bagi masyarakat Indonesia khususnya para petani dan pengusaha di bidang pertanian.

Saat ini BAF membiayai tiga jenis mesin pertanian dengan berbagai tipe dari dua Brand terkemuka yaitu KUBOTA dan YANMAR. Berikut adalah beberapa jenis mesin pertanian yang dibiayai oleh BAF: Mesin Tanam Padi, Mesin Panen Padi, Traktor Empat Roda

Pembiayaan Mesin Pertanian di BAF menggunakan skema Sewa Pembiayaan dengan hak opsi kepemilikan di akhir masa sewa selama 25 Bulan, 30 Bulan dan 36 Bulan. Tipe pembayaran dapat dipilih sesuai dengan keinginan dan kebutuhan konsumen yakni 1 bulanan (monthly), 3 bulanan (quarterly) dan 6 bulanan (semi annually). Selain itu, kami juga melayani "Angsuran Suka-Suka" yang mana konsumen bisa menentukan jumlah angsuran di setiap bulannya.

\section{Pembiayaan Multi Produk}

Tidak hanya melayani pembiayaan Sepeda Motor, BAF kini turut membantu konsumen dalam pembiayaan Multi Produk. Dengan pembiayaan Multi Produk, keinginan konsumen untuk memiliki alat elektronik maupun furniture yang selama ini diinginkan bukan lagi sekedar impian. Beberapa produk yang dibiayai oleh Multi Produk ini, antara lain:Handphone, Tablet, Kamera, Electronik Hiburan, Electronik Rumah Tangga, Aksesoris dan Perlengkapan Computer, Komputer, Laptop, Perlengkapan Dapur, Perlengkapan Kamar Tidur, Perlengkapan Ruang Keluarga, Alat Musik, Mesin Olah dan Penggerak, Peralatan Olahraga.

\section{Pembiayaan Syariah BAF}

Pembiayaan syariah di BAF yang dijalankan oleh Unit Usaha Syariah (UUS) sudah dimulai sejak tahun 2012 sebagai respon akan banyaknya permintaan konsumen atas pembiayaan dengan skema syariah. Sejak dikeluarkannnya POJK no 31/2014 tentang "Penyelenggaraan Usaha Pembiayaan Syariah" BAF kembali melakukan registrasi atas Unit Usaha Syariah (UUS) nya seperti yang diamanatkan oleh POJK tersebut.

Pembiayaan syariah di BAF yang saat ini dijalankan, baru ditujukan untuk pengadaan motor baru merek Yamaha dengan menggunakan akad "Murabahah". Namun demikian BAF juga merencanakan untuk mengembangkan Unit Usaha Syariah (UUS) nya untuk melakukan pembiayaan yang tidak terbatas kepada "Pembiayaan Barang" tapi termasuk juga "Pembiayaan Jasa" dan "Pembiayaan Investasi" dengan menggunakan akad "Ijarah", "IMBT (Ijarah Mumtahiyyah Bittamlik)", "Mudharabah" atau lainnya, juga atas obyek yang tidak terbatas pada motor baru merek Yamaha, tapi juga obyek lainnya seperti motor bekas, mobil baru, mobil bekas, alat pertanian, barang elektronik dan lainnya.

Pembiayaan pembiayaan syariah di BAF dilaksanakan dan dikembangkan oleh Unit Usaha Syariah (UUS) yang telah mendapatkan izin beroperasi yang terbaru sesuai Keputusan Anggota Dewan Komisioner OJK no KEP-129/NB.223/2015 tanggal 15 Juni 2015. Di bulan Juni 2015 itu pula, BAF Syariah telah mendapat izin operasional dari OJK atas 22 cabang.

BAF Syana (Syariah Dana) Syana (Syariah Dana) merupakan fasilitas pembiayaan kembali (ReFinancing) dengan menggunakan Prinsip Syariah bagi pemilik kendaraan bermotor (Roda Dua) untuk mememuhi berbagai macam kebutuhan. Kebutuhan mendesak saat ini ataupun dijadikan bentuk investasi masa depan.

PT Bussan Auto Finance (BAF) didirikan pada tahun 1997 dan merupakan perusahaan pembiayaan yang saat ini berkonsentrasi pada pembiayaan motor Yamaha. Saat ini BAF memiliki 173 kantor cabang di seluruh pelosok Nusantara, dengan jumlah karyawan lebih dari 10,000 orang. Total jumlah konsumen yang pernah dan sedang dibiayai oleh BAF telah mencapai lebih dari 4 juta orang. Selama tahun 2009, BAF membiayai lebih dari 714 ribu unit kendaraan bermotor baru dengan total asset lebih dari 10 triliun rupiah.

\section{Tanggung jawab Pembiayaan}

Tanggung jawab dalam arti hukum adalah 
tanggung jawab yang benar-benar terkait dengan hak dan kewajiban dan bersedia menanggung akibat atas kesalahan yang di lakukannya.

Di dalam perjanjian pembiayaan konsumen ada pihak-pihak yang terlibat yaitu;

a. Pihak dalam Perjanjian Pembiayaan dengan jaminan fidusia terdiri dari PT. Bursa Auto Finance (BAF) Rembang dengan debitur.

b. Pihak dalam perjanjian bersyarat terdiri dari Daeler atau showroom dengan debitur.

c. Pihak dalam perjanjian kerja sama terdiri dari PT. Bussan Auto Finance (BAF) Rembang dengan Dealer.

d. Pihak Notaris dengan PT. Bussan Auto Finance (BAF) Rembang.

Kreditur dan debitur, secara bersama-sama selanjutnya disebut dengan "para pihak", sepakat dan saling mengikatkan diri dalam suatu perjanjian pembiayaan konsumen dengan terlebih dahulu menerangkan hal ini yang menjadi dasar dari perjanjian pembiayaan ini, yaitu:

1. Fasilitas pembiayaan konsumen, Kreditur sepakat untuk memberikan fasilitas pembiayaan konsumen kepada debitur guna pembelian barang berupa kendaraan bermotor dan lain-lain.

2. Struktur pembiayaan konsumen, Fasilitas pembiayaan konsumen diberikan oleh kreditur kepada debitur dengan sistem pembiayaan yang akan disepakati bersama.

3. Pembayaran angsuran

a. Debitur wajib membayar angsuran selambatlambatnya pada saat jatuh tempo atau tanggal pembayaran yang telah disepakati secara tertib dan teratur tanpa terlebih dahulu dilakukan pemanggilan/pemberitahuan oleh Kreditur dengan cara apapun.

b. Jika jatuh tempo bertepatan dengan hari libur nasional, maka debitur wajib membayar angsuran selambat-lambatnya pada 1 (satu) hari kerja sebelumnya.

4. Bunga, denda dan biaya

a. Kreditur membebankan bunga atas pokok pembiayaan kepada debitur dan wajib dibayarkan dalam angsuran.

b. Debitur wajib membayar denda atas setiap keterlambatan pembayaran angsuran yang dihitung perhari dari jumlah angsuran yang terhutang sejak saat pada jatuh temponya hingga terbayarkannya angsuran tersebut.

c. Debitur menanggung setiap baban pajak atau barang dan biaya-biaya lain yang timbul sehubungan dengan fasilitas pembiayaan ini.

5. Hak dan kewajiban atas barang

a. Kreditur tidaklah penjual barang yang berupa kendaraan bermotor, karena tidak bertanggung jawab atas penyerahan, kualitas atau kondosi barang, baik yang terjadi pada waktu penyerahan barang dari dealer atau pada saat pemakaian oleh debitur,

b. Debitur sepakat untuk memelihara dan menjaga keutuhan barang (kendaraan bermotor) tersebut sebaik-baiknya dan memperbaiki segala kerusakan dengan biayanya debitur sendiri hingga setiap saat dan waktu berkala sehingga barang dapat digunakan sebagaimana mestinya.

c. Debitur sepakat untuk setiap saat atau waktu mengijinkan/memperbolehkna kreditur untuk memeriksa kondisi/keadaan barang dimanapun barang tersebut berada.

d. Debitur dilarang mengalihkan dengan cara apapun dan bagaimanapun termasuk menggadaikan , menjaminkan, menyewakan dan menjual barang, baik seluruh ataupun sebagian kepada pihak lain kecuali dengan persetujuan tertulis terlebih dahulu dari kreditur.

6. Asuransi

a. Apabila terjadi kerusakan, hilang atau musnahnya barang karena sebab apapun juga sepenuhnya menjadi tanggung jawab kreditur sesuai dengan ketentuan yang sudah menjadi aturan pada Bussan Auto Finance (BAF) Rembang

b. Kreditur wajib untuk mendaftarkan asuransikan seta membayar preminya terhadap barang yang menjadi objek jaminan fidusia.

7. Berakhirnya perjanjian, perjanjian pembiayaan dinyatakan berakhir apabila debitur telah melunasi semua angsuran dan denda apabila terjadi kepada kreditur sebagaimana kesepakatan kedua belah pihak.

8. Penyelesaian perselisihan, apabila terjadi terjadi perselisihan dari serangkaian peristiwa pelaksanaan perjanjian pembiayaan ini, maka jalan pertama yang ditempuh lewat jalur musyarawah, namun apabila jalur musyawarah tidak bisa disa diselesaikan maka memakai cara kedua yaitu para pihak sepakat memilih domisili hukum di Kantor Pengadilan Negeri yang wilayah hukumnya meliputi kantor cabang kreditur atau di 
tempat lainnya yang ditunjuk oleh debitur Hak Debitur:

1. Memperoleh kredit sesuai dengan pinjaman kredit yang telah disepakati atau disetujui bersama;

2. Debitur tetap mengusai benda jaminan fidusia;

3. Debitur tetap menerima hasil penjualan lelang benda jaminan fidusia tersebut;

4. Menerima kembali hak milik atas benda yang di jaminkan fidusia jika sudah melunasi utangnya sesuai perjanjian pembiayaan.

5. debitor ber hak untuk mempergunakan objek jaminan fidusia tersebut, dengan ketentuan bahwa debitor tidak boleh mengalihkan objek jaminan fidusia tanpa persetujuan dari pihak PT. Bussan Auto Finance (BAF) Rembang. Dan apabila terbukti mengalihkan objek jaminan fidusia tersebuk maka pihak debitor harus bertanggung jawab untuk menanggung biaya yang timbul dari proses penyitaan hingga penjualan objek jaminan fidusia tersebut, dan jika hasil dari penjualan tersebut tidak cukup untuk pelunasan hutang maka debitor harus tetap bertanggung jawab untuk membayar hutang yang belum dibayar.

Kewajiban Debitur:

1. Melunasi pinjaman pokok beserta bunga sesuai dengan waktu yang diperjanjikan

2. Menyerahkan surat bukti kepemilikan barang jaminan kepada kreditur;

3. Menjaga dan memelihara benda yang dijaminkan fidusia agar tetap pada kondisi pada saat diperjanjikan agar nilai benda yang dijaminkan tidak turun nilainya.

Hak Kreditur:

1. Menerima pelunasan utang dari debitur;

2. Mengambil barang yang dijaminkan debitur apabila debitur tidak mampu melunasi kreditnya.

Kewajiban kreditur:

1. Memberikan pinjaman sesuai dengan yang diperjanjikan;

2. Mengembalikan sisa hasil penjualan apabila ada kelebihan

3. Bertanggung jawab untuk menjaga barang jaminan berupa BPKB, dan apabila debitor sudah melaksanakan semua kewajibannya seperti melakukan pelunasan angsuran maka pihak kreditur wajib mengembalikan barang jaminan tersebut kepada pihak debitor.

4. Bertanggung jawab membuat Akta Jaminan Fidusia di hadapan Notaris lalu melanjutkan tanggung jawabnya dengan melakukan Pendaftaran Fidusia di kantor Pendaftaran Fidusia dalam hal ini di kuasakan kepada pihak Notaris, sebab Kreditur yang pertama kali mendaftarkan di Kantor Pendaftaran Fidusia maka ia adalah kreditur yang di utamakan dalam pelunasan hutangnya terhadap kreditur yang lain.

Dengan demikian pendaftaran jaminan fidusi memberikan hak yang didahulukan (preferen) kepada penerima fidusia terhadap kreditur yang lain. Ini disebabkan jaminan fidusia memberikan hak kepada penerima fidusia untuk tetap mengusai bendanya yang menjadi objek jaminan fidusia berdasarkan kepercayan. Perlindungan hukum bagi pihak kreditur dalam perjanjian kredit dengan jaminan fidusia sangat diperlukan, mengingat benda yang menjadi benda yang menjadi objek jaminan fidusia berada di tangan debitur, sehingga apabila debitur melakukan wanprestasi terhadap perjanjian kredit dengan jaminan fidusia, kepentingan kreditur dapat terjamin dengan adanya perlindungan hukum tersebut.

Perlindungan hukum terhadap kreditur ini di atur secara jelas dalam Pasal 1131 dan $1132 \mathrm{KUH}$ Perdata dan Undang-Undang Tahun 1999 tentang Jaminan Fidusia. Pasal 1131 KUH Perdata menyatakan, "segala kenendaan baik yang sudah ada maupun yang baru akan ada dikemudian hari menjadi tanggungan untuk segala perikatannya."

Pasal 1132 KUH Perdata menyatakan "kebendaan tersebut menjadi jaminan bersama-sama bagi semua orang yang mengutangkan kepadanya, pendapatan penjualan benda-benda itu dibagi menurut besar kecilnya piutang masing-masing, kecuali apabila diantara para berpiutang itu ada alasan-alasan yang sah didahulukan.'Pasal ini menjelaskan bahwa harta kekayaan debitur menjadi jaminan bagi para krediturnya. Hasil penjualan dibagi menurut imbangan masing-masing kecuali ada hak yang didahulukan.

Undang-Undang No.42 Tahun 1999 dalam hal ini menjelaskan perlindungan hukum bagi para pihak yang berkepentingan perjanjian kredit dengan jaminan fidusia, Pasal 11, 14, dan 15 UndangUndang Nomor 42 Tahun 1999 yang pada intinya menyebutkan bahwa benda yang dibebani dengan jaminan fidusia wajib didaftarkan kemudian dibuat sertifikat jaminan fidusia yang mencantumkan irahirah " DEMI KEADILAN DAN KETUHANAN YANG MAHA ESA", sehingga sertifikat jaminan fidusia 
mempunyai kekuatan eksekutorial yang sama kuatnya dengan putusan pengadilan yang telah memperoleh kekuatan hukum tetap. ${ }^{18}$

Adapun Tanggung Jawab pihak dealer adalah berkewajiban untuk mengurus dan menjamin kebenaran dan keabsahan surat-surat kendaraan seperti BPKB dan STNK tidak dalam sengketa atau di jaminkan kepada pihak ketiga. Karena pihak dealer harus bertanggung jawab secara hukum dan harus menanggung segala resiko yang timbul, sebab jika PT. Bussan Auto Finance (BAF) Rembang sudah mencairkan dana pembiayaan tersebut, namun setelah di kemudian hari terdapat perbedaan antara keadaan fisik kendaraan surat-surat kendaaran seperti BPKB atau STNK ataupun dalam keadaan sengketa maka pihak dealer harus mengmbalikan atau membayar kembali secara tunai atas seluruh fasilitas pembiayaan yang telah di bayar pihak kreditor dan juga mengembalikan uang pihak debitor. Akan tetapi dalam peraktek di lapangan apabila terjadi kesalahan berupa perbedaan antara data fisik kendaraan berupa, hal ini baru di ketahui oleh pihak yang kredit kendaraan setelah habis masa tanda nomor kendaraan bermotor (TNKB) untuk melakukan perpanjangan TNKB tersebut, setelah dilakukan cek fisik ternyata ada kekeliruan maka pihak yang melakukan kredit motor bingun tentang bagaimana cara menyelesaikan masalah tersebut berhubung pembelian kendaaran bermotor memakai jasa pembiayaan PT Bussan Auto Finance (BAF) maka pengurusan atas masalah tersebut di kembalikan ke PT Bussan Auto Finance (BAF) lalu kemudian dari pihak PT Bussan Auto Finance mengembalikan berkas tersebut ke dealer yang di ajak kemitraan tadi untuk menyalesaikan kekeliruan yang terjadi karena ketidak cocokan data fisik dengan sepeda motor yang di jadikan objek jaminan fidusia.

Mengenai hak Notaris adalah mendapat honor atas jasa yang diberikannya kepada Pihak kreditur, adapun kewajiban Notarisadalah mendaftarkan akta jaminan fidusia setelah diberi kuasa oleh Penerima fidusia, yang dikemudian hari karena kelalaiannya berakibat tidak didaftarkannya akta jaminan fidusia setelah para pihak yaitu debitur dan kreditur menandatangani akta jaminan fidusia, merupakan tanggung jawah sepenuhnya notaries yang bersangkutan.

\footnotetext{
18 Munir Fuady, 1995, Hukum Perkreditan Kontemporer, Citra Aditya Bakti, Bandung, h. 59
}

Jika notaris wanprestasi atau cidera janji, maka hal tersebut sangatlah merugikan Kreditur selaku penerima atau pemegang fidusia. Maka dalam hal ini Kreditur atau penerima fidusia dapat meminta tanggung jawab kepada notaries tersebut karena halhal yang tidak di inginkan berupa tidak mendaftarkan objek jaminan fidusia terjadi.

Notaris dikatakan melakukan wanprestasi (pihak yang berkewajiban karena diberi kuasa) tidak memenuhi isi perjanjian yang telah disepakati, yang berupa:

a. tidak melakukan apa yang telah disepakati dalam perjanjian

b. melaksanakan apa yang telah disepakati, tetapi tidak sebagaimana mestinya.

c. melakukan apa yang telah disepakati tetapi terlambat.

d. melakukan suatu hal yang menurut perjanjian tidak boleh dilakukan.

Pertanggung jawaban notaris atas kesengajaannya atau kelalainya atas pembebanan objek jaminan fidusia dan pendaftaran jaminan fidusia, apabila debitur atau pemberi fidusia melakukan wanprestasi sehingga merugikan penerima fidusia atau kreditur, maka dalam hal ini notaries yang telah diberi kuasa untuk melakukan pendaftaran dapat di gugat ke pengadilan, selanjutnya harus menerima putusan pengadilan berupa membayar ganti rugi kepada penggugat yang telah mengalami kerugian akibat perbuatan notaries yang telah melanggar hukum.

Adapun sanksi terhadap Notaris ada 2 (dua) macam, yaitu:

\section{Sanksi Perdata}

Sanksi ini berupa penggantian biaya, ganti rugi, dan bunga merupakan akibat yang akan diterima notaries atas tuntutan para penghadap jika akta yang bersangkuan hanya mempunyai kekuatan pembuktian sebagai akta dibawah tangan atau akta menjadi batal demi hukum.

Suatu akta yang batal demi hukum maka akta tersebut dianggap tidak pernah ada atau tidak pernah dibuat. Sesuatu yang tidak pernah dibuat tidak dapat dijadikan dasar suatu tuntutan dalam bentuk penggantian biaya, ganti rugi, dan bunga. Dengan demikian seharusnya suatu akta notaris yang batal demi hukum tidak menimbulkan akibat untuk memberikan penggantian biaya, ganti rugi, dan bunga kepada para pihak yang tersebut dalam akta.

Penggantian biaya, ganti rugi atau bunga dapat dituntut terhadap Notaris harus didasrkan pada suatu 
Vol 5 No 1 Maret 2018

hubungan hukum antara Notaris dengan para pihak yang menghadap para Notaris.Jika ada pihak yang merasa dirugikan sebagai akibat langsung dari suatu akta Notaris, maka yang bersangkutan dapat menuntut secara perdata terhadap Notaris. Dengan demikian, tuntutan penggantian baiaya, ganti rugi dan bunga terhadap Notaris tidak berdasarkan atas penilaian atau kedudukan suatu alat bukti yang berubah bersama karena melanggar ketentuan tertentu menurut Pasal 84UUJN, tapi hanya dapat didasarkan pada hubungan hukum yang ada atau yang terjadi diantara para Notaris dengan para penghadap.

Sebelum Notaris dijatuhi sanki perdata berupa penggantian biaya, ganti rugi dan bunga, maka terlebih dahulu harus dapat dibuktikan bahwa:

a. Adanya diderita kerugian.

b. Antara kerugian yang diderita dan pelanggaran atau kelalaian dari Notaris terhadap hubungan kausal.

c. Pelanggaran (perbuatan) atau kelalaian tersebut disebabkan kesalahan yang dapat dipertanggung jawabkan kepada Notaris yang bersangkutan.

2. Sanksi Administratif.

Secara garis besar sanksi administrative dapat dibedakan 3 (tiga) macam, yaitu:

a. Sanksi Reparatif;

Sanksi ini ditujukan untuk perbaikan atas pelanggaran tata tertib hukum.Dapat berupa pengghentian perbuatan terlarang, kewajiban perubahan sikap/tindakan sehingga tercapai keadaan semula yang ditentukan, tindakan memperbaiki suatu yang berlawanan dengan aturan. Contohnya paksaan untuk berbuat sesuatu untuk pemerintah dan pembayarannya uang paksa yang ditentukansebagai hukuman.

b. Sanksi Punitif; Sanksi yang bersifat menghukum, merupakan beban tambahan. Sanksi hukuman tergolong dalam pembalasan, dan tindakan prefentif yang menimbulkan ketakuatan kepada pelanggar yang sama atau pelanggar-pelanggar lainnya. Contohnya pembayaran denda kepada pemerintah, teguran keras.

c. Sanksi Regresif; Sanksi sebagai reaksi atas suatu ketidaktaatan, dicabutnya hak atas sesuatu yang diputuskan menurut hukum, seolah-olah dikembalikan kepada keadaan hukum yang sebenarnya sebelum keputusan diambil.Contohmya pencabutan, perubahan atau penangguhan suatu keputusan.
Dalam Pasal 85 UUJN ada 5 (lima) jensi Sanksi administratif yaitu:

a. Teguran lisan

b. Teguran Tertulis

c. Pemberhentian sementara.

d. Pemberhentian dengan hormat

e. Pemberhentian tidak hormat.

Penegakan hukum menurut ten Berge menyebutkan bahwa instrument penegakan hukum meliputi pengawasan dan penegakan sanksi, pengawasan merupakan langkah preventif untuk memaksakan kepatutan, dan penerapan sanksi merupakan langkah represif untuk memaksakan kepatutan. Dalam menegakkan sanksi administrative terhadap Notaris yang menjadi instrumen pengawas yaitu Majlis Pengawas yang mengambil langkahlangkah preventif, untuk memaksakan kepatuhan, untuk menerapkan sanksi yang represif, dan untuk memaksakan kepatutan agar sanki-sanki tersebut dapat dilaksanakan.

Langkah-langkah preventif dilakukan dengan melakukan pemeriksaan secara berkala 1 (satu) kali dalam satu tahun atau setiap waktu yang dianggap perlu untuk memeriksa ketaatan Notaris dalam menjalankan tugas jabatannya yang di lihat dari pemeriksaan protokolnya oleh Majelis Pengawas Daerah. ${ }^{19}$

Pertanggung jawaban Notaris terhadap akta jaminan fidusia yang dibuatnya atas kelalaian atau kesengajaan terhadap pembebanan objek jaminan fidusia dan pendaftaran jaminan fidusia, apabila Pemberi Fidusia atau Debitur melakukan ingkar janji (wanprestasi), maka Notaris yang diberi kuasa oleh Kreditur atau Penerima Fidusia untuk melakukan pendaftaran dapat di mintai pertanggung jawaban atas perbuatannya untuk menyelesaikan masalah baik berupa penyelesaian secara musyawarah atau digugat di Pengadilan dan Notaris harus menerima apa yang menjadi Putusan Hakim yang berkuatan hukum tetap, baik berupa mengganti kerugian atau pembatalan akta yang dibuatnya. ${ }^{20}$

Apabila dalam suatu perjanjian pihak Debitor tidak dapat melaksanakan apa yang telah di perjanjikan karena salahnya maka ia dapat dikatakan melakukan wanprestasi yang menyebabkan debitor

${ }^{19}$ Dr. Habib Adjie, SH., M.Hum, 2013, Sanksi Perdata dan Administratif Terhadap Notaris sebagai Pejabat Publik, PT. Refika Aditama, Bandung, h. 91-92

${ }^{20}$ Wawancara dengan Ibu Idda Indriaty Saptono, SH. Selaku Notaris-PPAT di Kabupaten Semarang. 
dapat dikenakan tuntutan baik secara perdata maupun pidana. Wanprestasi adalah tidak memenuhi atau lalai melaksanakan kewajiban sebagaimana yang ditentukan dalam perjanjian yang dibuat antara kreditur dan debitur. ${ }^{21}$

Berhubung terjadi adanya faktor kelalaian (wanprestasi) yang dilakukan oleh pihak debitur dalam hal pembayaran angsuran pada tiap bulannya atau tanggal yang sudah ditentukan atau disepakati bersama, dalam hal ini pembelian sepeda motor pada PT. Bussan Auto Finance (BAF) Cabang Rembang maka akan timbul akibat hukum atau resiko yang harus ditanggung oleh debitur.

Berdasarkan Pasal 1267 KUH Perdata yang menyebutkan bahwa: "Pihak terhadap siapa perikatan tidak dipenuhi, dapat memilih apakah ia, jika hal itu masih dapat dilakukan, akan memaksa pihak yang lain untuk memenuhi perjanjian, ataukah ia akan menuntut pembatalan perjanjian, disertai penggantian biaya kerugian dan bunga."

Dari bunyi Pasal tersebut diatas, bagi pihak yang merasa dirugikan dapat menuntut prestasi disertai ganti rugi kepada pihak yang telah dirugikan.

Dalam Pasal perjanjian Pembiayaan Konsumen dengan Jaminan Fidusia terdapat tata cara penyelesaian sengketa yang timbul antara para pihak yaitu dengan cara : Musyawarah, dan melalui Pengadilan Negeri Jakarta Selatan atau melalui Pengadilan Negeri lainnya di manapun juga dimana pihak kreditur mengajukannya. Upaya-upaya yang dilakukan oleh PT. Bussan Auto Finance (BAF) Rembang dalam proses musyawarah yaitu memberikan jangka waktu kepada pihak debitur untuk membayar angsuran yaitu dengan melalui surat peringatan atau somasi dengan tahap 1,2 dan 3. Dalam hal debitur wanprestasi berupa keterlambatan angsuran yang sesuai dengan tanggal jatuh tempo oleh debitor yaitu pada hari 1-7 maka ACC pusat di Kudus akan mengghubungidebitor melalui telepon untuk mengkonfirmasi agar debitor membayar agar angsurannya.

Jika dalam waktu 8 sampai 30 hari debitor tetap tidak melakukan kewajibannya dengan membayar angsuran, maka PT. Bussan Auto Finance (BAF) Rembang mengeluarkan somasi atau surat peringatan untuk pertama kalinya yang dikeluarkan oleh Acount Receivable Handling Officer(ARHO). Selain mengeluarkan somasi atau surat peringatan

\footnotetext{
21 Salim H.S., Hukum Kontrak dan Teknik Penyusunan Kontrak, Sinar Grafika, 2003, h. 98
}

ARHO juga mendatangi rumah atau tempat tinggal debitor lalu membicarakan pokok-pokok permasalahan. Jika pihak debitor tidak mengindahkan tidak mengindahkan somasi atau surat peringatan yang pertama dan saran $A R H O$, maka dari pihak PT. Bussan Auto Finance (BAF) Rembang akan mengeluarkan somasi atau surat peringatan kedua yang di keluarkan oleh Acount Recevaible Reposes Officer (ARRO), dengan jangka waktu 31 sampai 60 hari dan sudah keluar surat penarikan internal sehingga dapat menarik kendaran.

Jika dalam waktu 60 hari keatas Acount Receivable Reposes Officer (ARRO)tidak bisa menangani kasus tersebut maka akan di limpahkan ke Recovery Management Officer(REMO), kemudian pihak Recovery Management Officer (REMO) mengeluarkan surat kuasa penarikan eksternal untuk melakukan penarikan atau eksekusi terhadap kendaraan bermotor. Untuk tugas eksekusi atau penyitaan kendaraan di berikan surat kuasa resmi yang berstempel dan telah di tanda tangani oleh Operation head REMO (Recovery Management Officer), di pimpin oleh bapak Rudi yang bertugas hanya untuk mengkoordinasi Petugas Eksekusi Jaminan Fidusia (PEOJF) yang menerima kuasa melakukan proses eksekusi atau penarikan, dimana PEOJF ini bukanlah karyawan karyawan tetap tetapi sudah mempunyai hubungan kerja sama dengan PT. Bussan Auto Finance (BAF) Rembang. Adapun berkas-berkas yang disiapkan untuk melakukan penarikan atau eksekusi kendaraan yaitu : Foto copy Perjanjian Pembiayaan Konsumen, Foto copy Akta jaminan Fidusia, Sertifikat pendaftaran Fidusia, catatan history pembayaran, surat kuasa untuk melakukan penarikan/penyitaan objek jaminan fidusia.

Bahwa dalam proses eksekusi objek jaminan fidusia tersebut dapat dilakukan kapan dan dimana saja, hal itu karena PT. Bussan Auto Finance (BAF) sudah memenuhi kewajibannya untuk mendaftarkan objek jaminan fidusia di kantor Pendaftaran fidusia. Setelah dilakukan penarikan terhadap Objek Jaminan Fidusia tersebut maka debitur dikasih surat pernyataan oleh pegawai PT. Bussan Auto Finance (BAF) dua lembar untuk ditandatangani oleh pihak debitur atau penerima fidusia, satu lembar dibawa oleh petugas yang bersangkutan lembar kedua dikasihkan debitur untuk menyelesaikan masalah yang terjadi di kantor kreditur atau pemberi fidusia untuk memberikan kesempatanblagi agar dapat melunasi langsung semua pokok hutang, bunga, 
serta denda dalam jangka waktu 7 (Tujuh) hari.

Hal itu dapat dilihat dalam ketentuandalam Pasal Perjanjian Pembiayaan dengan Jaminan Fidusia PT. Bussan Auto Finance (BAF) Rembang dicantumkan tentang Kewajiban hutang debitor harus dibayar lunas. Berdasarkan hasil penelitian dilapangan jika pihak debitor tidak memberikan konfirmasi atas Surat Penyelesaian Hutang untuk pelunasan sekaligus hutangnya maka pihak kreditur akan melakukan penjualan barang jaminan di muka umum atau pelelangan. PT. Bussan Auto Finance (BAF) akan mengundang pihak dealer yang menjadi mitra bisnisnya. Penyelesaian sengketa melalui pengadilan adalah langkah terakhir yang ditempuh untuk menyelesaikan sengketa, jika jalan musyawarah tidak mencapai keputusan bersama maka pengadilanlah yang nantinya akan memutuskan tentang perselisihan tersebut.

Kepolisian Daerah Provinsi Sulawesi Tengah meyebut, leasing atau perusahaan pembiayaan kredit kendaraan dapat di jerat dengan hukum pidana bila melakukan penyitaan, penarikan atau pengambilan paksa kendaraan bagi konsumen penunggak kredit, tanpa adanya sertifikat dan pendapingan dari kepolisian.

Direktur Kriminal Khusus Polda Sulteng melalui Kasubdit I Bidang Industri dan Perdagangan , AKBP Teddy D Salawati menjelaskan, kendaraan yang menunggak serta mendapat dua kali peringatan, namun tetap tidak membayar maka eksekusi dapat dilakukan dengan pendampingan kepolisianbagi yang terdaftar dan bersertifikat jaminan fidusia.

"Kendaraan yang menunggak dapat dilakukan eksekusi oleh perusahaan leasing dengan pendampingan pihak kepolisian, namun harus terdaftar dan memiliki dan memiliki sertifikat jaminan fidusia," jelas AKBP Teddi Salawati. Dan ia menegaskan upaya pengambilan paksa atau merampas kendaraan menunggak yang dikredit oleh konsumen lewat perusahaan leasing tanpa ada sertifikat jaminan fidusia dapat dipidana dengan Pasal 362, 365 serta Pasal 55 dan 56 Kitab UndangUndang Hukum Pidana.

Teddy menguraikan jika ada konsumen yang menunggak atas kredit kendaraan melalui perusahaan "leasing" maka perusahaan itu dapat menggugat konsumen ke pengadilan perdata untuk mendapatkan putusan eksekusi. Hal itu, kata dia dibenarkan dan diberlakukan sesuai dengan ketentuan Undang-Undang Nomor 42 Tahun 1999
Tentang Jaminan Fidusia, bagi perusahaan" leasing" yang tidak memiliki jaminan sertifikat jaminan fidusia. Jika perusahaan leasing atau finance bahkan perusahan pemberi kredit tidak memiliki sertifikat jaminan fidusia, maka perusahaan itu harus menggugat konsumen melalui peradilan.

Ia mengingatkan jika ada tindakan oleh sipapun mengambil paksa dan atau merampas di jalan atau dimanapun tempatnya maka terhadap pelaku dan yang menyuruh dapat dipidana dengan Pasal 362 dan atau Pasal 365, atau pasal 55,56 KUHP. ${ }^{22}$

Pernyataan di atas selasat Otoritas Jasa Keungan (OJK) yang mengeluarkan peraturan terkait dengan eksekusi benda Jaminan oleh Perusahaan Pembiayaan di Pasal 21 sampai Pasal 24 dan pasal 50 ayat (4) Peraturan Otoritas Jasa Keuangan Nomor 29/POJK.05/2014 Tentang Penyelenggaraan Usaha Perusahaan Pembiayaan.

Pasal 21 (1) menyebutkan "Perusahaan Pembiayaan yang melakukan pembiayaan dengan pembebanan jaminan fidusia, wajib mendaftarkan jaminan fidusia dimaksud pada kantor pendaftaran fidusia, sesuai dengan undang-undang yang mengatur mengenai jaminan fidusia.

Pasal 21 (2) menyebutkan " Kewajiban pendaftaran jaminan fidusia sebagaimana dimaksud pada ayat (1) berlaku pula bagi Perusahaan Pembiayaan yang melakukan pembiayaan dengan pembebanan jaminan fidusia yang pembiayaannya berasal dari pembiayaan penerusan (channeling) atau pembiayaan bersama (joint financing).

Pasal 22 Menyebutkan " Perusahaan Pembiayaan wajib mendaftarkan jaminan fidusia pada kantor pendaftaran fidusia paling lambat 1 (satu) bulan terhitung sejak tanggal perjanjian pembiayaan".

Pasal 23 menyebutkan " Perusahaan Pembiayaan dilarang melakukan eksekusi benda jaminan fidusia apabila kantor pendaftaran fidusia belum menerbitkan sertifikat jaminan fidusia dan menyerahkannya kepada Perusahaan Pembiayaan.

Pasal 24 menyebutkan " Eksekusi benda jaminan fidusia oleh Perusahaan Pembiayaan wajib memenuhi ketentuan dan persyaratan sebagaimana diatur dalam undang-undang mengenai jaminan fidusia dan telah disepakati oleh para pihak dalam

22 Harianterbit.com Senin, 13 Maret 2017 13:31 WIB, Polisi:Leasing Dapat Dipidana Jika Lakukan PenarikanKendaraan Kredit, diunduh pada tanggal 20 Januari 2018. 
perjanjian pembiayaan.

Pasal 50 ayat (5) meyebutkan " Pegawai dan/atau tenaga alih daya Perusahaan Pembiayaan yang menangani bidang penagihan wajib memiliki sertifikat profesi dibidang penagihan dari lembaga yang ditunjuk asosiasi dengan menyampaikan pemberitahuan kepada OJK dan disertai dengan alasan penunjukan. ${ }^{23}$

Dari serangkaian langkah-langkah yang di atas yang diambil oleh Perusahahaan Pembiayaan bila debitur berbelit-belit dalam memberikan keterangan terhadap benda yang menjadi objek jaminan fidusia dapat menjadi indikator benda tersebut beralih ke pihak ketiga, larangan dalam mengalihkan objek jaminan fidusia tanpa persetujuan tertulis dari pihak kreditor sudah diatur secara tegas dalam Pasal 23 ayat(2) Undang-Undang No 42 tahun 1999 sedangkan dalam Pasal 36 Undang-Undang No 42 tahun 1999 yang mengatur tentang hukuman dan denda jika pihak debitor mengalihkan Objek Jaminan Fidusia tanpa persetujuan tertulis dari pihak kreditor.

Pasal 23 ayat (2) Umdang-undang No 42 tahun 1999 mengatakan ; "Pemberi Fidusia dilarang mengalihkan, menggadaikan, atau menyewakan kepada pihak lain benda yang menjadi objek jaminan fidusia yang tidak merupakan benda persediaan, kecuali dengan persetujuan tertulisterlebih dahulu dari penerima fidusia"

Setelah debitor baru mengaku sudah mengalihkan objek jaminan Fidusia kepada pihak ketiga tanpa persetujuan tertulis dari pihak PT. Bussan Auto Finance (BAF) Rembang. Jika sudah mengetahui objek jaminan Fidusia dialihkan, ARHO juga mendatangi pihak ketiga untuk menyarankan melakukan proses oper kredit resmi dari PT. Bursa Auto Finance (BAF) Rembang dan menjelaskan tentang resiko-resiko yang dihadapi jika melakukan oper kredit secara resmi.

Dalam pengertian barang pakai habis termasuk juga dalam sejumlah uang oleh pemberi pinjaman.Pemberi pinjaman adalah perusahaan pembiayaan konsumen yang berkedudukan sebagai kreditor sedangkan peminjam adalah konsumen yang berkedudukan sebagai debitur. Karena barang pakai habis yang dipinjamkan itu sejumlah uang, maka menurut ketentuan Pasal 1765 KUHPerdata (Perusahaan Pembiayaan Konsumen dan Konsumen) boleh memperjanjikan pengembalian uang pokok di

\footnotetext{
${ }^{23}$ Peraturan Otoritas Jasa Keuangan Nomor 29/POJK.05/2014
}

tambah bunga. Berdasarkan uraian di atas, dapat disimpulkan bahwa perjanjian pembiayaan konsumen tergolong perjanjian khusus yang objeknya adalah barang pakai habis yang diatur dalam Pasal 17541773 KUHPerdata.

Pelanggaran terhadap ini menyebabkan dapat dikenakan tuntutan pidana penggelapan sesuai dengan ketentuan Pasal 372 Kitab Undang-undang Hukum Pidana yang menyatakan: "Barang siapa dengan sengaja dan melawan hukum mengaku milik sendiri (zich tooiegenen) barang sesuatu yang seluruhnya atau sebagian adalah kepunyaan orang lain, tetapi yang ada dalam kekuasaannya bukan karena kejahatan, diancam karena penggelapan dengan pidana penjara paling lama empat tahun atau denda paling banyak enam puluh ribu rupiah".

Dikategorikan melakukan tindak pidana penggelapan karena dalam perjanjian pembiayaan konsumen dengan jaminan fidusia ini pihak debitor hanya sebagai pihak peminjam, karena jaminan fidusia berupa Bukti Pemilikan Kendaraan Bermotor (BPKB) ada di pihak kreditur yaitu PT. Bussan Auto Finance (BAF) Rembang, sedangkan pihak debitur belum melunasi angsurannyA namun sudah mengalihkan objek jaminan fidusia tanpa persetujuan tertulis dari pihak PT. Bussan Auto Finance (BAF) Rembang

\section{PENUTUP}

\section{Kesimpulan}

Dari pembahan yang telah diurakan di atas, maka dapat diambil kesimpulan, sebagai berikut:

1. Tanggung Jawab Para Pihak Dalam Pembuatan Akta Jaminan Fidusia Pada Notaris dan Peyelesaian Sengketanya.

Antara para pihak yaitu kreditur dan debitur dalam perjanjian pembiayan yang telah disepakati timbul hak dan kewajiban yang harus disepakati biar tidak terjadi kesalah pahaman dikemudian hari yang merugikan debitur. Jika di temukan di kemudian hari perbedaan antara Surat kelengkapan kendaraan dengan Fisik Kendaraan maka tanggung jawab ada di Pihak Dealer juga bias lewat bantuan Leasing.

PT. Bussan Auto Finance (BAF) Rembang dalam Melakukan Perjanjian Pembiayaan dengan Debitur dilakukan pula perjanjian fidusia yang dibuat melalui pemberian kuasa di bawah tangan oleh debitur kepada Kepala Kantor Cabang Rembang dan Kepala kantor Pusat di Jakarta.

Notaris bertanggung jawab atas kebenaran yang 
diutarakan di dalam akta perjanjian jaminan fidusia yang dibuatnya bila dikemudian hari terjadi sengketa di kemudian hari menyangkut kepemilikan objek jaminan fidusia.

2. Akibat Hukum dan Proses penyelesaian Sengketanya Jika Debitur Mengalihkan Kendaraan Objek Jaminan Fidusia Kepada Pihak Ketiga Tanpa Persetujuan Tertulis Dari PT. Bussan Auto Finance (BAF) Rembang,

3. Upaya-upaya yang di lakukan oleh PT. Bussan Auto Finance (BAF) Rembang apabila Debitur Wanprestasi:

a. Melakukan penagihan, melalui pemberitahuan tertulis berupa surat somasi tentang penagihan dan peringatan dengan tahap 1, 2 dan 3.

b. Apabila surat somasi tidak di indahkan oleh debitur, maka PT. Bussan Auto Finance (BAF) Rembang, pertama akan melakukan pendekatan secara persuasif terlebih dahulu tidak dengan melakukan penyitaan terhadap benda yang menjadi objek jaminan, kedua akan menempuh jalur pengadilan bila menyangkut objek jaminan yang begitu besar.

Debitur yang sudah dan mengikatkan diri terhadap perjanjian pembiayaan dengan jaminan fidusia dilarang mengalihkan benda yang menjadi objek jaminan fidusia dilarang mengalihkan kepada pihak ketiga tanpa persetujuan tertulis oleh pihak kreditur, apabila di kemudian hari tejadi pengalihan objek jaminan fidusia maka debitur akan bisa kena tuntutan hukum berupa pidana denda maupun penjara. Untuk melakukan eksekusi benda Jaminan fidusia PT. BAF Rembang mengedepankan prinsip musyawarah dengan persetujuan tertulis dahulu dari pihak debitur.

\section{Saran}

1. Untuk debitur, meskipun perusahaan pembiayaan menawarkan banyak kemudahan dalam membeli barang dengan cara mengangsur atau kredit, debitur harus membaca dan memahami surat perjanjian kontrak pembiayaan dengan jelas, sebelum melakukan kesepakatan kontrak pembiayaan dengan multifinance, setelah menandatangani perjanjian kontrak pembiayaan, debitur haruslah memenuhi kewajiban membayar angsuran secara tepat waktu sesuai besaran dan tanggal yang telah disepakati, supaya jangan sampai ada konflik atau kesalah pahaman yang bisa merugikan debitur di kemudian hari

Untuk kreditur, alangkah baiknya setiap lembaga pembiayaan dalam melakukan setiap perjanjian haruslah dibuat dengan akta notariil, memang memakai jasa notaris berarti mengeluarkan biaya tambahan dalam pembuatan setiap akta perjanjiannya, namun demikian itu biaya yang dikeluarkan oleh lembaga pembiayaan akan sepadan dengan resiko hukum yang akan dihadapi. Oleh karena itu, untuk perjanjianperjanjian yang memiliki nilai ekonomis atau berisi suatu hal yang sangat penting bagi lembaga pembiayaan agar dibuat dalam bentuk akta notaris (akta otentik) agar perjanjian tersebut memiliki kekuatan pembuktian yang sempurna

akibat hukum dari perjanjian yang Fidusia yang dibuat tanpa menggunakan bentuk Akta Notariil dan tidak didaftarkan, maka perjanjian tersebut hanyalah berupa akta dibawah tangan yang tidak mempunyai kekuatan eksekutorial untuk mengeksekusi langsung barang yang ada dalam penguasaan konsumen.

2. Hal-hal yang harus di pahami kreditur maupun debitur mengenai prosedur penarikan kendaraan bermotor dari debitur oleh perusahaan pembiayaan:

a. Debitur perlu memastikan bahwa proses eksekusi benda jaminan fidusia telah sesuai dengan prosedur yang diatur dalam perjanjian pembiayaan termasuk mengenai tahapan pemberian surat peringatan kepada debitur/konsumen.

b. Petugas yang melakukan eksekusi jaminan fidusia merupakai pegawai perusahaan pembiayaan atau pegawai alih daya perusahaan pembiayaan yang memiliki surat tugas untuk melakukan eksekusi benda jaminan fidusia.

c. Petugas yang melakukan eksekusi benda jaminan fidusia membawa sertifikat jaminan fidusia, alangkah baiknya eksekusi dilakukan dengan pendampingan dari kepolisian.

d. Proses penjualan barang hasil eksekusi benda jaminan fidusia harus dilaksanakan sesuai dengan ketentuan peraturan peraturan perundang-undangan mengenai jaminan fidusia.

\section{DAFTAR PUSTAKA}


Bambang Sunggono, 1998, Metode Penelitian Hukum, Raja Grafindo Persada, Jakarta

Djuhaendah hasan, 1996, Lembaga Jaminan Kebendaan Bagi Tanah dan Benda Lain yang Melekat Pada Tanah Dalam Konsepsi Penetapan Asas Pemisahan Horisontal, PT. Citra Aditya Bakti, Bandung

Gunawan Widjaya dan Ahmad Yani, 2001,Jaminan Fidusia, Raja Grafindo Persada Jakarta

Habib Adjie, SH., M.Hum, 2013, Sanksi Perdata dan Administratif Terhadap Notaris sebagai Pejabat Publik, PT. Refika Aditama, Bandung

Herlien Boediono, 2006, Asas Keseimbangan Bagi Hukum Perjanjian Indonesia (Hukum Perjanjian Berlandaskan Asas-asas Wigati Indonesia), PT. Citra Adiyta Bakti, Bandung

--------, 2012,Kumpulan Tulisan Hukum Perdata dibidang Kenotariatan, Citra Aditya Bakti, Bandung

J. Satrio, .2002, Hukum Jaminan Hak Kebendaan Fidusia, PT. Citra Aditya Bakti, Bandung

M. Ali Mansyur, 2008, Hukum Perdata Perikatan, Unissula Pers, Semarang

2011, Hukum Perdata Jaminan, Bagian Kukum Perdata F.H. UNISSULA, semarang

Munir Fuady , 2003, Jaminan Fidusia Revisi Kedua, Citra Aditya Bakti, Jakarta

Rony Hanitijo Soemitro, 1988, Metode Penelitian Hukum dan Jurimetri, Ghalia Indonesia, Jakarta

Salim H.S., 2013, Hukum Kontrak dan Teknik Penyusunan Kontrak, Sinar Grafika

Soerjono Soekanto, 1986, Pengantar Penelitian Hukum, Universitas Indonesia Pers, Jakarta

Soerjono Soekanto dan Sri Mamuji, 1985, Penelitian Hukum Normatif-Suatu Tinjauan Singkat,
Rajawali Pers, Jakarta

Suharnoko, 2004, Hukum Perjanjian Teori dan Analisis Kasus, Prenada Media, Jakarta

Undang-Undang Nomor 10 Tahun 1998 tentang Perbankan

Undang-Undang Nomor 42 Tahun 1999 tentang Jaminan Fidusia

Undang-Undang Nomor 8 Tahun 1999 tentang Perlindungan Konsumen

Peraturan Pemerintah Nomor 21 Tahun 2015 tentang Tata Cara Pendaftaran Jaminan

Fidusia dan Biaya Akta Jaminan Fidusia

Peraturan Menteri Keuangan RI Nomor 130/PMK.010/Tahun 2012 tentang Pendaftaran Jaminan Fidusia bagi Perusahaan Pembiayaan yang Melakukan Pembiayaan Konsumen Untuk Kendaraan Bermotor dengan Pembebanan Jaminan Fidusia Peraturan Otoritas Jasa Keuangan Nomor 29/POJK.05/2014 tentang Penyelenggaraan Usaha Perusahaan Pembiayaan.

Surat Keputusan Direksi Bank Indonesia No. 23/88/KEP/DIR Tahun 1991 tentang Jaminan Pemberian Kredit

http://baf.id diunduh pada tanggal 10 Agustus 2017

http://cermati.com diunduh pada tanggal 10 Agustus 2017

http://dahlaniskan.wodpress.com diunduh pada tanggal 1 Juli 2017

http://harianterbit.com diunduh pada tanggal 20 Januari 2018

http://hukumonline.com diunduh pada tanggal 1 Juli 2017

http://Gatranews.com diunduh pada tanggal 1 Juli 2017

Knowledgeisfree.blogspot.com 15 oktober 2015, di unduh tg 20 januari 2018. 